\title{
The Role of Institutional Pillars on Mobile Learning Adoption in a Developing Country's Higher Education Institution
}

\author{
Harriet Koshie Lamptey \\ University of Professional \\ Studies, Accra
}

\author{
koshlamptey@gmail.com
}

\begin{abstract}
Mobile devices are becoming vital components of human activities. An example is the use of mobile in learning which is gaining popularity in higher education. However studies that account for reasons underlying mobile learning adoption in developing countries (DCs) are limiting in existing literature. This study investigates the role of institutional elements on mobile learning adoption in a higher education institution. As a relatively young concept in Ghana, there are few studies in this area. This study seeks to address the gap. This qualitative case study is on distance education delivery at a public institution. Interviews were used to gather data. The new Institutional theory provided illumination for the study. Analysis revealed that institutional elements play different roles in the adoption process. The study recommends the pursuit of procedures that can help sustain legitimacy of m- learning in higher education.
\end{abstract}

Keywords: developing country, distance education, higher education institution, mobile learning, institutional theory.

\section{Introduction}

Wireless technology development has been on the ascendency in recent times [1]. Mobile technology has diffused rapidly in comparison to other wireless modes of communication. Enhancements in mobile technology have resulted in five generations [2]. Pervasiveness of the technology is revolutionizing several aspects of human life [3]. Associated with this is a proliferation of various wireless- supported portable devices. Their affordability, availability and ease of use have turned these devices into indispensable components of human endeavors and modern society [4]. Mobile phones are popular devices for wireless communication globally [5].

Improvements in the processing capabilities and storage capacities of mobile devices have extended their primary function as communication and entertainment tools to educational aids [6]. This suggests that their prior make as simple devices have changed into complex gadgets in response to changing trends and user needs. Subsequently, advancements in mobile phone manufacture brought about smartphones which in addition to voice and data exchanges, possess complex computing and Internet permeation abilities [7]. For example smartphones with their associated applications are reported to be changing the face of participatory health care in several countries [8]. Again, there has been fusion of mobile and multimedia technology to host and support searches for a vast amount of electronic information [9]. As a result of the fusion of multimedia with mobile technology, which was heralded by the third generation, mobile television and mobile journalism begun [10]. In another sphere of modern society, [11] reports that in Africa, citizen involvement in democratic activities have been accelerated by mobile phone usage in a manner that is transforming individuals and groups. In an earlier study, [12] identified the potential of mobile phones to cause social disruptions.

The rest of the article is thus structured: the article proceeds with a brief account of mobile learning (mlearning) adoption in HEI followed by the theoretical under pinning of the study. The research design, which is a case is provided next. Findings are followed by a discussion. Contributions and recommendations are made. The study ends with acknowledged limitations.

\section{Mobile learning adoption in HEI}

As a result of improved functionalities, the usage scenarios of mobile devices have broadened, involving impulsive, casual, relative, handy, ubiquitous, prevalent and peculiar situations [13]. This diversity has paved a path for devices to be used as aids in education. M- learning is the latest addition to modes of erudition. It has been applied at various levels of education [14]. In higher education, it is being used in combination with other methods to augment 
instructional delivery for persons who cannot enroll on regular programs [15]. Consequently, the landscape of higher education institutions (HEI) is being affected by the penetration of mobile devices and technology. A striking rise in the use of mobiles by students in college is reported [16]. The tech- savvy nature of young adults provides an opportunity for HEI to harness during learning strategies formulation.

The adoption theme dominates both developed and developing country (DC) literature. Some noted adoption sub- themes are user acceptance [17], institutional readiness [18], usage intention [19], user perceptions [20] and user attitudes [21]. Other research areas include systems development issues on design [22] and implementation [23]. In addition, influential factors regarding various research perspectives like developmental challenges [24], learning success [25] and platform success [26] have been researched.

M- learning adoption is becoming a widely researched area. There are studies on various disciplines like mathematics [27] and science [28]; and on professional programs like teacher development [29], nursing [30] and medicine [31]. Language learning is a popular area where $\mathrm{m}$ - learning studies abound [32]. However, some adoption sub themes are absent or vaguely reported in studies. [33] regret that there is a myth surrounding $\mathrm{m}$ - learning adoption in DCs. The underlying reasons and influential factors on adoption are often unaccounted for. In a recent review, [34] noted that a majority of studies are on formal environments, involve language instruction and focus on impact, and suggested the need for studies that will consider learning beyond the walls of the classroom Thus this study investigates $\mathrm{m}$ - learning adoption in distance education (DE). It seeks to unravel factors influencing adoption by trailing the activities involved to provide understanding in an area with limiting studies.

\section{Theoretical background}

The propensity for communal arrangements and practices to autonomously gain strength and importance is the core concept of Institutional theory [35]. Institutional theory seeks to explain the manner in which plans, standards, tasks and procedures are organized to shape social behavior. It also provides clarification on how social structures are created, accepted, used and discarded over time. Social structures survive through ways that aid their stability [36]. Though stability appears to be its main theme, advocates of the theory are inevitably exposed not only to agreement and conventionality but to dissentions and transformation in social structures in some situations. The theory recognizes formal institutions that have compulsory rules and standards and in addition, informal institutions that are persistent collections of communally shaped values that shape thought, reasoning, actions and decisions [37].

The theory has undergone transformation in both development and application. Limitations of the old Institutional theory paved way for the new. Some earlier proponents of the new institutional theory include [38] and [39]. Based on the epic work of [38], [39] re- molded the whole idea of the new- institutional theory, by re-grouping earlier constructs into three basic building blocks of institutions which he termed pillars. These are the regulative, normative and cognitive elements which are connected yet distinct portions of legitimacy within institutions [40]. The regulative pillar seeks to sustain institutions, through enactment, compliance and monitoring of laws. Whiles internal rules increase organizational efficiency, external rules empower organizations. The normative pillar denotes personal and structural types of behavior founded on the compulsory side of shared, constructive and expert relations [40]. The cultural- cognitive pillar denotes specific actions founded on laws and procedures crafted through a steady personal understanding which controls opinions and behavior [41].

The institutional lens has been applied in the information Systems (IS) field on researches concerning various phenomena. Most IS scholars tend to focus on the benefits of institutionalism embedded in IS phenomena in organizational settings to the neglect of the disadvantages imposed [42]. The effect of institutionalization on IS has dominated studies. Limiting are the institutional processes that produce the observable effects. In this regard, [42] advocate for study perspectives that involve IS institutional procedures and suggest a blend of institutional theory with other theories to increase understanding of complex concepts. Similarly, [43] in a review of fiftythree IS studies revealed that most studies adopt a passive view of the theory, leaving a majority of the basic principles of Institutional theory unaddressed. Moreover there seems to be a general lack of institutional theory in educational technology research. Studies on m- learning adoption guided by institutional theory are currently limiting in literature. Secondly, mlearning institutionalization research is also unrepresented. A study by [44] on institutionalization of science courses in higher education in seven countries was not guided by the theory. [45] applied the theory to technology adoption and implementation in a middle- school district, that is in a first cycle schooling context. [46] reports that IS studies guided by institutional theory do not focus on new systems or 
ones that fail. Hence institutional theory is chosen to address this gap in extant literature. The theory presents a shift from technology- centered ideas of IS theories to actions within communally- shaped environments. The theory's consideration of userfactors can contribute to social aspects of IS adoption that are sometimes unreported.

This study aims to uncover the role of institutional elements in the adoption of $\mathrm{m}$ - learning in a DE department of an HEI in Ghana. The study aims to provide answers to the following questions: How was mobile learning adopted? What role did institutional elements play in the adoption process? What has been the experience of users (students) with engagement? Hence this research adopts the Institutional theory to improve its use in the IS discipline and m- learning studies at the HEI level.

\subsection{Conceptual framework}

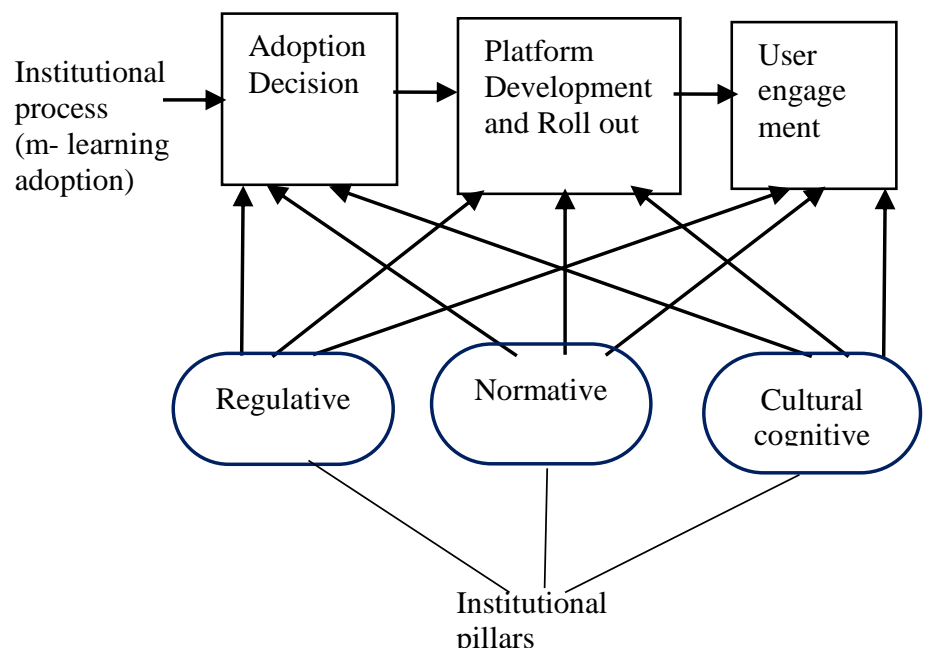

"Figure 1. A representation of institutional elements on m- learning adoption".

Figure 1 is a developed framework to guide the study. It illustrates a simplified process of $\mathrm{m}$ - learning adoption as occurs in HEI with the three institutional elements in operation. Arrow signs indicate the direction of the pillar on institutional activities. All institutional actions and structures are under the influence of theses pillars.

\section{Research Design}

\subsection{Case study}

A qualitative methodology was chosen. It allows the fusion of data gathered from different sources to provide better understanding of participant responses [47]. A single- case study design backed by an exploratory strategy was used [48]. Though findings cannot be generalized it enables institutional constructs to provide fresh insights into $\mathrm{m}$ - learning adoption [49]. Unreported non- technical aspects of m- learning adoption can be revealed.

\subsection{The case: A public HEI in Ghana}

In a quest to find solutions to issues that confront them, HEI are constantly seeking ways to improve existing processes, especially in relation to teaching and learning. Though $\mathrm{m}$ - learning is not the first adopted form of technology- enabled learning, it is becoming a reckoning process. Evidence of $\mathrm{m}$ learning in Ghanaian HEI is relatively young [50]. Reports on its early adoption are about four years [51]. It is being used in blended mode in DE settings where regular programs are unsuitable for some students.

A public institution that offers $m$ - learning in blended mode for DE delivery was selected. The reason for selection is based on the fact that the case represents the phenomenon under investigation [48]. It has moderately invested in its ICT infrastructure and continues to improve conditions for technologysupported leaning. For example, a customized version of an open- source Learning Management System (LMS), MOODLE is currently in use by the university. The Moodle platform of the institution has been configured to the local area network of a local communications services provider to provide better management and support. A DE department was established eight years ago. There are about one hundred and sixty students presently. The initial mode of learning material transfer was through printed resources. In August 2010, DE by electronic delivery began. This was a pilot program involving a few courses. After commencement of at the main campus, branch campuses (learning centers) were set up in all regions to improve access to tertiary education, especially for those from resource constrained regions. With increasing preference by students for hand held devices during face- to face and interactive sessions, an $\mathrm{m}$ - learning steering committee was established to supervise the incorporation of $\mathrm{m}$ - learning.

\subsection{Study participants}

There are three categories of people (actors) made up of administrators, lecturers and students at S2. Only actors involved in $\mathrm{m}$ - learning were included in the study. Administrators function as facilitators of the process. Users are lecturers who use the platform for teaching and students who are involved in studying. 
Six participants from each group were chosen. Participants were purposively selected to provide appropriate data for the study [52].

\subsection{Data collection method}

Questions were framed on the guide proposed by [53] since it provides a means of comprehensively gathering data on Institutional theory. Data was gathered over a four month period. Care was taken to frame questions from the perspective of a participant group to improve relevance in responses. Individual interview sessions were held for data collection. A smart phone was used to record interview sessions. Data transcription was manually performed. Procedures to ensure data quality were also followed [54]. For example, care was taken during interview sessions to instill objectivity in the process. Similarly, clarity was a focus of the transcription exercise.

\subsection{Data analysis}

The qualitative data analysis method used involves four inter- connected stages: data collection, reduction, display and conclusion drawing [55]. After manual transcription of interview records, the volume of data was reduced through summarization and coding with emphasis placed on inclusion of important facts [56]. Responses of each participant group were summarized separately. Coding involved a two- step process. Initial codes were descriptive text derived from actor perceptions on the role of institutional pillars on adoption. A second coding scheme sought to draw single- worded actor experiences regarding engagement. Tables were used to display categorized data.

\section{Findings}

\subsection{M- learning adoption process at $\mathrm{S} 2$}

Access to tertiary education is a challenge in Ghana and some qualified applicants are denied yearly due to spatial issues [57]. Technology- enabled learning is being used to alleviate the issue. The adoption process begun with newly purchased server computers and upgrades on some existing systems. The mobile communication infrastructure was also improved with support from a local telecom services operator. Content development was performed from scratch using course development teams. A team comprises lecturers, educationalists, and trainers. Lecturers possess knowledge in a particular subject area. Educationalists serve as mentors for a group and trainers support the use of tools. The blend in a team serves as a complementary- mix in the writing exercise. To avoid conceding on worth, each team is replicated to improve writing and material (output) quality. The DE department has an in- house developed template for course writing in a three- staged training process. The first stage which is pre- training assesses lecturers' competence. This next stage involves training and team- building. Lecturers define the scope of content. Some aesthetic features may be added by trainers to improve appearance and readability. The final stage is an evaluation exercise that determines whether the group has developed suitable content- specific material in the subject area. Accepted content is uploaded onto the Moodle platform. If not the previous stages of the writing exercise are repeated to correct and improve output. The three- staged course- writing exercise enforces writing and content standards. Conversion of written resources into multimedia formats is also ongoing at S2. The aim of multimedia conversion is to facilitate learning by matured students. Presently, a Mobile Web is not yet developed, hence the steering team uses systems interoperability techniques to enable resources conversion between Internet and mobile applications.

An Information Technology Services (ITS) department is responsible for deployment and training. Training is separately organized for lectures and students at the start of an academic year. Again, training is provided for on- line information searches to help users access relevant content that can improve their knowledge in a subject area.

Two distinct models are in operation for On-line teaching and learning. One is the blended model for local students and a purely electronic model for foreign students. For local students, tutorials form part of instructional delivery. Lecturers facilitate tutorials for academic courses whiles field experts are brought in to handle industry- based courses. A facilitator's reason given for this was:

"Tertiary education is necessary for the job market and we align our programs with on- demand professions. That is why we invite practitioners to handle specific areas of some courses. The essence is to orient the minds of students in class to what pertains in practice. And as you know, academic and professional perspectives differ."

Study materials uploads, assignments, discussion forums and revision activities are compulsory for users. Assignments are conducted on- line but examinations require a physical presence. A task force tracks participation in the specified activities. DE facilitators conduct surveys at the end of each semester to ascertain progress of specified activities. The survey report is used to solve issues and fill gaps in existing 
procedures. The practice is also to prevent undetection of issues that can result in deterioration of the process of $\mathrm{m}$ - learning in DE.

\subsection{User perceptions on the role of institutional pillars on $\mathbf{m}$ - learning adoption}

\section{"Table 1. A summary of user perceptions on the role of institutional pillars on $\mathrm{m}$ - learning adoption".}

\begin{tabular}{|c|c|c|c|}
\hline \multirow{2}{*}{$\begin{array}{l}\text { Instit } \\
\text { ution } \\
\text { al } \\
\text { pillar }\end{array}$} & \multicolumn{3}{|c|}{ Summary of participant group responses } \\
\hline & Administrators & Lecturers & Students \\
\hline $\begin{array}{l}\text { Regul } \\
\text { ative }\end{array}$ & $\begin{array}{l}\text { 1. Important to } \\
\text { the institution's } \\
\text { internationalizati } \\
\text { on aim. } \\
\text { 2. M- learning is } \\
\text { part of our } \\
\text { strategic plan. } \\
\text { 3. No internal } \\
\text { regulatory } \\
\text { enforcement yet. } \\
\text { 4. Partnership to } \\
\text { support ICT } \\
\text { infrastructural } \\
\text { development. } \\
\text { 5. Involved in } \\
\text { innovative } \\
\text { processes } \\
\text { planning. }\end{array}$ & $\begin{array}{l}\text { 1. Adoption } \\
\text { aimed at } \\
\text { broadening } \\
\text { access. } \\
2 \text {. M- } \\
\text { learning is } \\
\text { unsuitable } \\
\text { for some } \\
\text { programs. }\end{array}$ & $\begin{array}{l}1 . \\
\text { Unaware } \\
\text { of } \\
\text { policies }\end{array}$ \\
\hline $\begin{array}{l}\text { Norm } \\
\text { ative }\end{array}$ & $\begin{array}{l}\text { Locally } \\
\text { accredited } \\
\text { programs }\end{array}$ & $\begin{array}{l}\text { Far reaching } \\
\text { content } \\
\text { delivery }\end{array}$ & $\begin{array}{l}\text { Faster } \\
\text { program } \\
\text { completi } \\
\text { on times }\end{array}$ \\
\hline $\begin{array}{l}\text { Cultu } \\
\text { ral- } \\
\text { cogni } \\
\text { tive }\end{array}$ & $\begin{array}{l}\text { Positive } \\
\text { perceptions } \\
\text { about the future } \\
\text { of m- learning }\end{array}$ & $\begin{array}{l}\text { Eager to see } \\
\text { platform } \\
\text { maintained } \\
\text { and process } \\
\text { sustained }\end{array}$ & $\begin{array}{l}\text { Trendy } \\
\text { and } \\
\text { popular } \\
\text { with } \\
\text { younger } \\
\text { students }\end{array}$ \\
\hline
\end{tabular}

Source: author's construct

Table 1 is a summary of actor perceptions on the role of institutional pillars on m- learning adoption. External state regulations played a significant role at the pre- adoption stage. Administrators admit that no formal internal policy exists yet. When questioned on the reasons why a policy has not yet been formulated an administrator's reply was:

"There is an institutional strategic plan we follow, though it has not been endorsed as a policy. The underlying reason for our De program is to improve tertiary education accessibility for locals. The incorporation of technology was to gain a global presence and become international. Fortunately, we have been able to gain students from other parts of Africa and Asia. As we get established in the area of technology- enabled learning, policy formulation will follow. We are taking things gradually."

The institution has an internationalization intent that seems to be favored by the adoption strategy. Lecturers view the adoption process as a means of broadening access but some are of the view that mlearning is unsuitable for programs that involve structural design and practice. However, students were unaware of regulations guiding adoption. In the stages ensuing implementation, the effect of the regulative pillar seems to be taken over by the other two pillars.

Normative influences dominate development and training whiles the cultural element dominates engagement. Norms define goals of communal groups. $\mathrm{S} 2$ is striving to create an image by establishing teaching and learning in electronic environments in order not to be outpaced by younger institutions. Administrators revealed that leadership are not stagnant with technology adoption but are exploring innovative ways to stay competitive with the current techno- dynamic society. Another administrator's view regarding the role of norms in m- learning adoption was:

"Yes, m- learning has begun and there is a steering committee. Since it is relatively young, we have not attained full establishment. We go through rigorous processes in developing content as you have seen. We constantly need to upgrade and modify our systems so we can continue to attract our target students. Since we do not have all the competencies, we have formed external partnerships to maintain the smooth running of the process."

When questioned on perceptions regarding institutional norms on the adoption process, a lecturer replied:

"Oh, it is moderately high. I contributed to content development that was used at the start. The thought increases my-self- worth. I have not taken part in a resource conversion exercise so this is my first experience. I am glad to be part of the initiators."

From the view of students, adoption has led to efficiently relayed information that enables faster completion of coursework.

The cultural- cognitive pillar reflects important beliefs of actors in communities. The general belief among DE facilitators at S2 is that the onset of smart phones triggered $\mathrm{m}$ - learning adoption by students. Noted cultural traits exhibited by state- owned institutions towards novel systems has been the reverse in this case. In institutional settings, values may change as time progresses [39]. Thus, the cultural- cognitive 
barrier of actor indifference exhibited by public institutions is fading- out, perhaps as a result of the perceived benefits of $\mathrm{m}$ - learning. There are two divergent views of students regarding adoption. Whiles matured students are not fond of m- learning, younger students are. A student in favor of $\mathrm{m}$ - learning adoption's reason was:

"I prefer to have all resources for my program in my hand, on my personal phone than to carry a knapsack around campus. I cannot make references to notes in some places, but with my phone, you can't tell what I am actually doing. Convenient and trendy."

\subsection{User experiences with m- learning engagement}

"Table 2. A summary of actor responses on mlearning engagement".

\begin{tabular}{|l|l|l|}
\hline $\begin{array}{l}\text { Actor } \\
\text { group }\end{array}$ & Experience factor & $\begin{array}{l}\text { Descriptive } \\
\text { response }\end{array}$ \\
\hline $\begin{array}{l}\text { Administ } \\
\text { rators }\end{array}$ & Platform set- up & Satisfactory \\
\cline { 2 - 3 } & $\begin{array}{l}\text { Mobile application } \\
\text { development }\end{array}$ & $\begin{array}{l}\text { Sometimes } \\
\text { challenging }\end{array}$ \\
\cline { 2 - 3 } & $\begin{array}{l}\text { Mobile content } \\
\text { development }\end{array}$ & Challenging \\
\cline { 2 - 3 } & $\begin{array}{l}\text { Multi- } \\
\text { development }\end{array}$ & Preliminary \\
\hline \multirow{5}{*}{ Lecturers } & Moodle LMS interface & Good \\
\cline { 2 - 3 } & Internet connectivity & Satisfactory \\
\cline { 2 - 3 } & Platform access & Satisfactory \\
\cline { 2 - 3 } & $\begin{array}{l}\text { Use: content and } \\
\text { assignment uploads }\end{array}$ & $\begin{array}{l}\text { Sometimes } \\
\text { challenging }\end{array}$ \\
\hline Students & Moodle interface & Simple \\
\cline { 2 - 3 } & Internet connectivity & Satisfactory \\
\cline { 2 - 3 } & Resource access & Easy \\
\cline { 2 - 3 } & $\begin{array}{l}\text { Actual learning } \\
\text { experience }\end{array}$ & $\begin{array}{l}\text { Convenient but } \\
\text { not elaborate }\end{array}$ \\
\hline
\end{tabular}

Source: author's construct

Table 2 is a summarized display on user experiences with m- learning engagement. Lecturers believe that m- learning grants unrestricted resource access to students which facilitates faster instructional delivery. A lectures experience with current instructional delivery was:

"Now tutorial sessions no longer require in- depth teaching. I offer clarifications on areas that students find challenging. It is more of a discussion forum. I think it will improve faculty research output compared to the days of purely traditional learning."

Another lecturers' opinion on the flexibility currently associated with tutorials was:
"Lecturers no longer have to verbally deliver lengthy lectures, I emphasize on important areas for students to assimilate. This reduces the strain of standing and speaking for long hours."

Currently, majority of DE students at S2 engage in $\mathrm{m}$ - learning. It is common to have most students in a face to face discussion make reference to subject notes on their phones. Students who use tablets and I-pads are a minority. However the responses of students were mixed with regards to $\mathrm{m}$ - learning engagement. Whiles some were happy, others were not. A student complained about phone compatibility with modified applications on the platform by stating:

"You see, sometimes I am not able to see everything on my phone in the manner in which others do and this bothers me."

When questioned further on the possible reason, the reply given was that:

"I think the operating system on my phone conflicts with that of the platform and modified applications. I just hope the ITS can work around it to alleviate such occurrences soon. It slows everything for me."

Some mobile applications that work well on the platform and on some popular smartphone brands are being modified to help control this problem and is only being used by a group of students. Again, slow links during high usage scenarios was also reported as an issue and students are advised to resort to offline access during the time. Some young students described $\mathrm{m}$ - learning as convenient as compared to the matured who are less technologically inclined.

\section{Discussion}

In HEI an adoption decision stage precedes the development, roll- out and subsequent use of systems. The decision stage may involve a series of council meetings before leadership agree upon it. The reason is that public HEI are bound by external regulations [58]. The regulative pillar is portrayed by laws, rules and authority that act as forceful instruments with legal sanctions as their legitimate basis [53]. Rules are handed down as directives from authority that must be abided by. Decision making must therefore follow procedures that help instill sanity in institutions.

[59] identified two main types of policies in Ghanaian HEI: state and institution- specific. Governmental regulations are enforced by the state whiles institutional laws are internally generated rules aimed at forcing the realization of the institution's objectives. Governmental policies on HEI apply to all tertiary institutions (public and private). Adherence to external rules is strengthened by actors within an institution [60]. 
In the year 2008, the government of Ghana passed a legislation on the use of ICTs in all education sectors to augment existing processes and improve computer literacy for the schooling public. A regulatory pressure developed from the enactment of this law. As establishments within the social and political context of Ghana, the actions of HEI are influenced by their external environment [61]. Actors exist in institutions that also belong to socio- political environments, which portrays institutional embeddedness [62]. Compliance to this Act granted institutional leaders the obligation to opt for alternate forms of teaching and learning. The implementation of this law introduced changes in some existing processes in HEI. Included is the use of mobile devices as a means to support learning and improve participation in higher education. At S2, the adoption process was influenced by an external regulation. Public institutions that refute governmental laws can face punitive measures that may trigger other problems.

Institutions have a tendency of incorporating new ideas, forms and processes as a powerful myth [63]. Compliance to the political rule to adopt advancing technologies into education is becoming a powerful myth. This is evident at S2 which is under compulsion to adhere to governmental regulations. Myths have a tendency to interfere with internal arrangements [64]. Hence HEI should take caution to separate uncertainties of technological arrangements from real work activities. This is a practical example of the classic decoupling mechanism envisioned by neoinstitutionalists [63]. By separating the technological artefact from the desired activity (learning), HEI can better identify issues and respond to changing conditions to become more stable [65]. This places emphasis on the actual activity, which is students' learning. Mobile devices and technology play an enabling role in the process. The check keeps DE facilitators focused and prevents deviation from intended outcomes. Thus, caution is necessary when technology is used in erudition.

The impartation and practice of transferring beliefs, notions and ideals across generations is termed culture [66]. In institutional theory, the cultural- cognitive pillar concerns structures that shape meaning through collective ideas about communal truth [39]. In relation to $\mathrm{m}$ - learning adoption, it provides answers on the beliefs of actors in HEI regarding the use of technology in education [67]. Presently, there is a general 'it's all right' or sometimes 'it is necessary' belief regarding technology use not only in educational spheres, but across diverse industries [68]. There appears to be a cultural cognitive aspect to $\mathrm{m}$ - learning adoption among HEI. An adoption decision without surety of outcomes based on close competitor- monitoring in a field is a sign of field pressure. Though the quality and success of the program was unassured, S2 was not deterred. The idea that an institution is in high standing because of its cybernetic presence is another factor. This is an example of a taken for granted ideology steered by institutional culture that may have influenced m- learning adoption at S2 [69]. Again, there are no reports on actor opposition to the formal adoption rules. Lecturers did not see the adoption exercise as a threat against their collective norms in this case [70].

S2 is one of the oldest HEI in Ghana It adopted after a close competitor, believed be a trendsetter in higher education did. A private HEI had embarked on $\mathrm{m}$-learning earlier but that failed. The trendsetter was however able to sustain adoption. Institutions within a particular field may follow certain rules and practices not because they are beneficial but because they are accepted by the wider community [71]. There is a possibility that S2 adopted to foster acceptance and improve its image among field members. Mimicking is common practice in institutional fields [72]. Mimicking can turn adoption into a field induced process. This represents the highest state of institutional legitimacy. In this scenario, m- learning adoption is influenced by social acceptability rather than convenience.

Adaptation to recognized communal standards leads to institutional isomorphism [39]. Isomorphism represents the development of a fit between organizations and their field in which the relationship between an institution and its environment becomes one of appropriateness [73]. There is a potential that Ghanaian HEI pursuing a common $\mathrm{m}$ - learning objective will turn isomorphic with time. There is evidence of a developing $\mathrm{m}$ - learning institutionalization process. There seems to be uncertainty regarding sustainability of $\mathrm{m}$ - learning should another innovative technology emerge. Therefore the recognition needed to legitimize $\mathrm{m}$ learning has not been fully developed. Institutionalization attainment will depend on how well platforms are maintained and processes improved to constantly achieve desirable learning outcomes with time.

\section{Contribution and recommendations}

The study investigated $\mathrm{m}$ - learning adoption in a public HEI in a DC. The current state of studies on DCs do not focus on social aspects regarding technology adoption. This study addressed the gap by investigating a less explored area. A lesson learnt from this study is that institutional pillars play different roles 
in a technology adoption process. Another lesson is that the regulative pillar is a driving force in adoption in state- owned institutions. Again, the culturalcognitive pillar plays a veiled but forceful role in directing beliefs and actions within institutions. If beliefs are positive, adoption intents and processes are favored, if not, good decisions and intents may fade away.

Facilities improvement and maintenance to reduce existing limitations of connectivity and resource compatibility are needed to promote continuous use of $\mathrm{m}$ - learning. Instructional design needs periodic checks to improve delivery and alleviate challenges during use. Though students are motivated, some complained that delivery and learning styles are getting routine. The environment needs to be kept exciting by frequently introducing novel methods to broaden the scope of instructional delivery. Students will then be exposed to learning options they find convenient. Without these cautionary measures in place at $S 2$, the $\mathrm{m}$ - learning environment may deteriorate, ruining intended results of students learning via mobiles on DE programs.

\section{Study limitations}

The study was conducted over a four month period after which user participation may have changed due to process improvements by program facilitators. Current experiences may result in deviations from reports of this study.

\section{References}

[1] M. Coccia. "The source and nature of general purpose technologies for supporting next K-waves: Global leadership and the case study of the US Navy's Mobile User Objective System", Technological Forecasting and Social Change, 2017, 116, 331-339.

[2] P. Parashar, N. Chauhan, and S. K. Gonsai, "Basics of $5 \mathrm{~g}$ technology and its evolution", International Research Journal of Engineering and Technology, 2017, 4(4), 2007-2008.

[3] Traxler, J. Education and the Impact of Mobiles and Mobility. In Medienbildung in neuen Kulturräumen VS Verlag für Sozialwissenschaften, 2010.

[4] Ling, R. Mobile communication. In Dialogues on Mobile Communication, Routledge, 2016.

[5] Statistics, G. M. Part A: Mobile Subscribers worldwide, 2014, Retrieved May, $11^{\text {th }} 2014$ from

http://mobithinking.com/mobile-marketing-tools/latestemobile-stats/a\#subscribers

[6] G. Duman, G. Orhon, and N. Gedik, "Research trends in mobile assisted language learning from 2000 to 2012”, ReCALL, 27(02), 197-216, 2015.
[7] M. Anshari, M. N. Almunawar, M. Shahrill, D. K. Wicaksono, and M. Huda, "Smartphones usage in the classrooms: Learning aid or interference"? Education and Information Technologies, 2017, 22(6), 3063-3079.

[8] M. N. K .Boulos, S, Wheeler, C, Tavares, and R. Jones, "How smartphones are changing the face of mobile and participatory healthcare: an overview, with example from eCAALYX", Biomedical Engineering Online, 2011, 10 (1), 24.

[9] F. Liu, Y. Liu, Y. Liu, and H. Wang, "A novel construction paradigm of multimedia awareness system for mobile network" Cluster Computing, 2017, 1- 17.

[10] O. Westlund, "Mobile news: A review and model of journalism in an age of mobile media", Digital Journalism, 2013, 1(1), 6-26.

[11] H. Wasserman, "Mobile phones, popular media, and everyday African democracy: Transmissions and transgressions", Popular Communication, 2011, 9(2), 146-158.

[12] Wright, L. The Causes of New Threats. In People, Risk, and Security, 25-38, Palgrave Macmillan, London, 2017.

[13] Sharples, J., Taylor, J., and G. Vavoula, A theory of learning for the mobile age. In Medienbildung in neuen Kulturräumen, (pp. 87-99). VS Verlag für Sozialwissenschaften, 2010.

[14] C. K. Looi, D. Sun, D, L. Wu, P. Seow, G. Chia, L.H. Wong, E. Soloway, and C. Norris, "Implementing mobile learning curricula in a grade level: Empirical study of learning effectiveness at scale." Computers \& Education, 2014, 1(77), 101-15.

[15] A. Kukulska-Hulme, M. Sharples, M., Milrad, M., I. Arnedillo-Sánchez, and G. Vavoula, "Innovation in mobile learning: A European perspective", International Journal of Mobile and Blended Learning (IJMBL), 2009, 1(1), 13-35.

[16] U. Lee, J. Lee, M. Ko, C. Lee, Y. Kim, S. Yang, K. Yatani, G. Gweon, K. M. Chung and J. Song "Hooked on smartphones: An exploratory study on smartphone overuse among college students", In Proceedings of the 32nd annual ACM conference on Human factors in computing systems 2014, 2327-2336.

[17] Wong, K., F. L. Wang, K. K. Ng, and R. Kwan, Investigating acceptance towards mobile learning in higher education students. InTechnology in Education. Transforming Educational Practices with Technology, 2015 (pp. 9- 19), Springer, Berlin, Heidelberg.

[18] A. K. Almasri, "The influence on mobile learning based on technology acceptance model, mobile readiness and perceived interaction for higher education students", International Journal of Technical Research and Applications, 2014, 2 (1), 5-11.

[19] J. S. Mtebe, and R. Raisamo, 'Investigating students' behavioral intention to adopt and use mobile learning in higher education in East Africa", International Journal of Education and Development using Information and Communication Technology, 2014, 10(3), 4. 
[20] A. Al-Hunaiyyan, S. Al-Sharhan, and R. Alhajri, "A New Mobile Learning Model in the Context of the Smart Classrooms Environment: A Holistic Approach", International Journal of Interactive Mobile Technologies, 2017, 11 (3), 39-56.

[21] M. Al-Emran, H. M. Elsherif, and K. Shaalan, "Investigating attitudes towards the use of mobile learning in higher education". Computers in Human Behavior, 2016, 56, 93-102.

[22] N. Gedik, A. Hanci-Karademirci, E. Kursun, and K. Cagiltay, "Key instructional design issues in a cellular phone-based mobile learning project", Computers \& Education, 2012, 58(4), 1149-59.

[23] Osang, F. B., J. Ngole, and C. Tsuma, Prospects and Challenges of Mobile Learning Implementation in Nigeria. Case Study National Open University of Nigeria NOUN. In International Conference on ICT for Africa, 20 (pp. 20-23), 2013.

[24] A. C. Setirek, and Z. Tanrikulu, "Significant Developmental Factors that can affect the Sustainability of Mobile Learning". Procedia-Social and Behavioral Sciences", 2015, 191, 2089-96.

[25] S. Yodsaneha and S. Sopeerak "Factors Influencing the success of Rajamangala University of Technology Thanyaburi's ubiquitous learning", Procedia-Social and Behavioral Sciences, 2013 26(103), 400-403.

[26] M. Alrasheedi and L. F. Capretz "An empirical study of critical success factors of mobile learning platform from the perspective of instructors", Procedia-Social and Behavioral Sciences. 2015 2(176), 211- 219.

[27] Z. Taleb, A. Ahmadi, and M. Musavi, "The effect of mlearning on mathematics learning". Procedia-Social and Behavioral Sciences", 2015, 171, 83- 89.

[28] Y. M. Huang, Y. T. Lin, and S. C. Cheng, "Effectiveness of a mobile plant learning system in a science curriculum in Taiwanese elementary education". Computers \& Education, 2010, 54, (1), 4758.

[29] S. Y. Ekanayake, and J. Wishart "Integrating mobile phones into teaching and learning: A case study of teacher training through professional development workshops", British Journal of Educational Technology. 2015, 46(1), 173- 189.

[30] N. J. Lee, S. M. Chae, H. Kim, J. H. Lee, H. J. Min, and D. E. Park, "Mobile-Based Video Learning Outcomes in Clinical Nursing Skill Education: A Randomized Controlled Trial", Computers, Informatics, Nursing, 2016, 34(1), 8 .

[31] R. F. Liu, F.Y. Wang, H. Yen, P. L. Sun, C. H. Yang, "A new mobile learning module using smartphone wallpapers in identification of medical fungi for medical students and residents". International Journal of Dermatology", 2018, 57(4), 458- 462.

[32] Brown, D. Informal Language Learning with Mobile Technology for Acquisition of Non-native Languages. In Society for Information Technology \& Teacher Education International Conference, pp. 723-726,
Association for the Advancement of Computing in Education (AACE), 2018.

[33] A. S. Al-Adwan, A. Al-Adwan and H. Berger, "Solving the mystery of mobile learning adoption in higher education", International Journal of Mobile Communications, 2018, 16(1), 24- 49.

[34] H. Crompton, and D. Burke, "The use of mobile learning in higher education: A systematic review", Computers \& Education. 2018, 123, 53-64.

[35] L. Fuenfschilling, and B. Truffer, "The structuration of socio-technical regimes: Conceptual foundations from institutional theory", Research Policy, 2014, (4), 772791.

[36] I. Cardinale, "Beyond Constraining and Enabling: Toward New Micro foundations for Institutional Theory", Academy of Management Review, 2018, 43(1), 132- 155.

[37] W. Kaufmann, R. Hooghiemstra and M. K. Feeney, "Formal institutions, informal institutions, and red tape: A comparative study", Public Administration, 2018, 96(2), 386-403.

[38] P. J. DiMaggio, and W. W. Powell, "The iron cage revisited: Institutional Isomorphism and Collective Rationality in Organization Fields", American Sociological Review, 1983, 48, 147- 160.

[39] W. R. Scott, "Institutions and Organizations: Ideas and Interests, 3rd Edition (Thousand Oaks: Sage), 2008a.

[40] M. Lipnicka, and J. Verhoeven, "The application of New Institutionalism and the Resource Dependency theory for studying changes in universities within Europe. Roczniki Nauk Spolecznych, 2014, 42(4), 730.

[41] H. Wang, J. Tseng, and Y. Yen, "How do institutional norms and trust influence knowledge sharing? An institutional theory", Innovation: Management, Policy \& Practice, 2014, 16(3), 374- 391.

[42] W. L. Currie, and E. B. Swanson, "Special issue on institutional theory in information systems research: contextualizing the IT artefact. Journal of Information Technology, 2009, 24(4), 283-285.

[43] M. Mignerat, and S. Rivard, "Positioning the Institutional Perspective in Information Systems Research", Journal of Information Technology, 2009, 24(4), 369- 391.

[44] Zapp, M. Higher Education Expansion and the Growth of Science: The Institutionalization of Higher Education Systems in Seven Countries, 1945-2015. In The Century of Science: The Global Triumph of the Research University, pp. 37-53. Emerald Publishing Limited, 2017

[45] A. J. Lamb, and J. M. Weiner, "Institutional Factors in iPad Rollout, Adoption, and Implementation: Isomorphism and the Case of the Los Angeles Unified School District's iPad Initiative", International Journal of Education in Mathematics, Science and Technology. 2018, 6(2), 136- 154. 
[46] J. Baptista, S. Newell, and W. Currie, "Paradoxical Effects of Institutionalization on the Strategic Awareness of Technology in Organizations," Journal of Strategic Information Systems, 2010, 9(3), 171- 183.

[47] R. E. Stake, Qualitative Case Studies, in N. K. Denzin \& Y. S. Lincoln (Eds.), Strategies of qualitative enquiry, $3^{\text {rd }}$ ed., pp. 119- 150. Thousand Oaks, CA: Sage. 2008.

[48] R. K. Yin, Case study research: Design and methods, Sage Publications, 2014.

[49] T. Laine, T. Korhonen and M. Martinsuo, "Managing program impacts in new product development: An exploratory case study on overcoming uncertainties. International Journal of Project Management, 2016, 34(4), 717-733.

[50] S. Asunka, Instructor Perceptions and Intentions to Use a Tablet PC for Mobile Learning in a Ghanaian University: An Exploratory Case Study, In Handbook of Research on Mobile Devices and Applications in Higher Education Settings, (pp. 495-517). IGI Global, 2016.

[51] N. Y. Asabre, "Towards a perspective of Information Communication Technology in (ICT) learning: Migration from Electronic Learning (E- learning) to Mobile Learning (M- learning)", International Journal of Information and Communication Technology Research, 2012, 2(8), 646-649.

[52] Edmonds, W. A., and T. D. Kennedy, An applied reference guide to research design: Quantitative, qualitative and mixed methods, Thousand Oaks, CA: Sage, 2012.

[53] W. R. Scott, Institutional theory Pp. 408-14 in Encyclopedia of Social Theory, George Ritzer, ed. Thousand Oaks, CA: Sage. (2004b).

[54] S. Bascadara, "How spreadsheet applications affect information quality", Journal of Computer Information Systems, 2011, 51(3), 77- 84

[55] M. B. Miles, and A. M. Huberman, Qualitative data analysis: An expanded sourcebook, $2^{\text {nd }}$ Sage; Thousand Oaks, CA, 1994

[56] I. Mayer, "Qualitative research with a focus on data analysis". International Journal of Sales, Retailing and Marketing, 2015, 4(9), 53- 67.

[57] M. A. Tagoe, "Making real the dream of education for all through open schooling and open universities in Ghana," SAGE Open. 2014, 4(4).

[58] K. Blind, "The influence of regulations on innovation: A quantitative assessment for OECD countries", Research Policy. 2012, 41(2), 391-400.

[59] J. K. Arthur, K. S. Adu-Manu, and C. Yeboah, "A conceptual framework for the Adoption of Social Network Technologies (SNTs) in Teaching-case of Ghana", International Journal of Computer Science, 2013, 10(5), 70-8.

[60] C. Osei-Amponsah, A. van Paassen, and L. Klerkx, "Diagnosing institutional logics in partnerships and how they evolve through institutional bricolage: Insights from soybean and cassava value chains in Ghana", NJAS-Wageningen Journal of Life Sciences, 2018, 84, $13-26$.

[61] Y. Cai, "Graduate employability: A conceptual framework for understanding employers' perceptions", Higher Education, 2013, 65(4), 457- 469.

[62] B. Szkudlarek, and S. X. Wu, "The culturally contingent meaning of entrepreneurship: mixed embeddedness and co-ethnic ties", Entrepreneurship \& Regional Development, 2018, 30(5-6), 585-611.

[63] J. W. Meyer, and B. Rowan, "Institutionalized organizations: formal structure as myth and ceremony", American Journal of Sociology, 1977, 83, pp. 340- 363.

[64] C. Biesenthal, S. Clegg, A. Mahalingam, and S. Sankaran, "Applying institutional theories to managing megaprojects", International Journal of Project Management, 2018, 36(1), 43-54.

[65] S. Furnari, "Institutional fields as linked arenas: Interfield resource dependence, institutional work and institutional change", Human Relations, 2016, 69(3), 551- 580 .

[66] S, H. Schwartz, "Rethinking the concept and measurement of societal culture in light of empirical findings", Journal of cross-cultural Psychology, 2014, 45(1), 5- 13.

[67] I. Arpaci, "A comparative study of the effects of cultural differences on the adoption of mobile learning", British Journal of Educational Technology, 2015, 46(4), 699712 .

[68] C. Zhu, "Organizational culture and technologyenhanced innovation in higher education. Technology", Pedagogy and Education, 2015, 24(1), 65- 79.

[69] A. Alesina, and P. Giuliano, "Culture and institutions". Journal of Economic Literature. 2015 53(4), 898- 944.

[70] A. C. Pache, and F. Santos, "Embedded in hybrid contexts: How individuals in organizations respond to competing institutional logics". Research in the Sociology of Organizations, 2013, 39, 3- 35.

[71] W.W. Porter, C. R. Graham, R. G. Bodily, and D. S. Sandberg, "A qualitative analysis of institutional drivers and barriers to blended learning adoption in higher education", The internet and Higher education, 2016, 28, 17- 27.

[72] R. Dubey, A. Gunasekaran, and S. S. Ali, "Exploring the relationship between leadership, operational practices, institutional pressures and environmental performance: A framework for green supply chain", International Journal of Production Economics, 2015, 160, 120- 132 .

[73] C. Shu, K. Z. Zhou, Y. Xiao, and S. Gao, "How green management influences product innovation in China: The role of institutional benefits", Journal of Business Ethics, 2016, 133(3), 471- 485. 
Page 42 